\title{
MONITORING OF KEY INDICATORS OF THE STATE DEBT OF UKRAINE: MODERN TRENDS
}

\author{
LYUTYY IGOR \\ Doctor of Economics, Professor \\ Chief of Finance Department \\ Taras Shevchenko National University of Kyiv, Ukraine \\ yljuda@ukr.net
}

\section{NAKONECHNA YULIIA}

PhD in Economics, Associate Professor,

Taras Shevchenko National University of Kyiv, Ukraine

tematika@ukr.net

\section{DEMYDENKO LIUDMYLA}

$\mathrm{PhD}$ in Economics, Associate Professor,

Taras Shevchenko National University of Kyiv, Ukraine

ipr.demydenko@gmail.com

KEYWORDS: PUBLIC DEBT OF UKRAINE, GUARANTEED BY THE STATE DEBT, INTERNAL LENDERS, EXTERNAL LENDERS, DEBT SERVICING, DEBT SECURITY, GOVERNMENT DEBT POLICY, PUBLIC FINANCES.

For citation: Lyutyy I., Nakonechna Y., Demydenko L. (2019), Monitoring of Key Indicators of the State Debt of Ukraine: Modern Trends, Globalization And Business, №8, pp. 34-43. https://doi.org/10.35945/gb.2019.08.003

\section{INTRODUCTION}

In the context of the reform of public finance management in Ukraine, the need to form an effective debt policy of the state, including mastering the main methods of public debt management, such as monitoring of the indicators of state and guaranteed debt of Ukraine, is important.

The monitoring of public debt is a process of constant monitoring of the indicators of state debt in dynamics and in comparison with the main macro indicators, which allows to assess the quality of debt policy in modern conditions.

The purpose of this article is to monitor the indicators of state and state-guaranteed debt in the context of the need to ensure the sustainability of public finances.

The subject of the study is the practical aspects of monitoring the indicators of Ukraine's public debt in the conditions of ensuring the macro-fiscal stability and improving the quality of management in the field of public finances in Ukraine.

The object of the research is the process of forming the state debt of Ukraine.

The theme of state debt is paid to the attention of a wide range of foriegn and domestic researchers, among which the most well-known works are A. Auerbach, W. Gale, A. Krupkin, T. Bogdan, V. Lisovenko, O. Horn, L. Sidelnikova, V. Fedosov, I. Chugunov, and others. At the same time, the question arises of the need to introduce monitoring of public debt indicators on a regular basis in order to implement effective tactics and strategies for managing public debt in Ukraine. The analytical report "Debts: time to take and time to give. Global Trends and Challenges for Ukraine "[12] focuses on a comparative analysis of fiscal parameters and debt load in different countries, the issue of external debt in Ukraine.

\section{RESEARCH METHODOLOGY}

The methodological basis of the writing of the article became the general scientific methods of cognition (dialectics, analysis, synthesis, systemicity, analogy, historicism, system analysis). The article uses the generally accepted methodology for calculating the main indicators characterizing the state's debt policy. The method of expert assessments analyzes the condition of the state debt and prospects of its servicing in Ukraine. Statistical and analytical methods have been used for 
the processing of statistical data on the study of the dynamics of indicators of state and state-guaranteed debt in Ukraine.

The sources of information were the materials of the Ministry of Finance of Ukraine, the State Treasury Service of Ukraine, as well as the Budget Code of Ukraine, laws and regulations of Ukraine relating to the budget sphere, scientific works of domestic and foreign scientists.

Further research with the use of expert and documentary methods of the consequences of reforms to ensure the quality of public administration in the field of public finances in Ukraine and the identification of its results will be required, as reflected in the following publications.

In the context of representative democracy, the taxpayer as a user of public services and as a citizen is mostly interested in three things: the number and quality of public services and their value personally for him. Measures, methods and financial instruments that ensure financial stability and welfare in the country are the competence of public financial management bodies. Their main task is to establish a clear relationship between the level of satisfaction of public needs and product indicators, costs, efficiency and effectiveness of the use of budget funds, as well as provide the necessary conditions for optimizing the debt burden on the state budget. The borrowed funds affect the processes of economic life of the state, may act as a tool for revitalizing the socio-economic development of the state, and, conversely, as a factor in the strengthening of financial risks, which adversely affects the ability of the state's financial system to sustain and ensure sustainable economic growth.

The need to finance the budget deficit causes the expansion of the state's internal and external borrowing and affects the growth of government debt, but significant budget expenditures, deficit, and public debt are not in themselves destructive factors of the economy.

In the opinion of the well-known economist J. Stiglitz, new jobs and economic growth do not arise if they release workers and reduce public spending. Taking advantage of the tactics of a radical cut in public spending, US President Herbert Hoover "broke" the stock market crash to a great deal of depression. Regarding state debt problems, J. Stiglitz recalls the fact that a decade ago, when, at that time, Federal Reserve Chairman A. Greenspan was concerned, the current budget surplus could cause the payment of all national debt, which would complicate the implementation of monetary policy, in particular the sphere of raising (decreasing) the interest rate, through the sale (purchase) of treasury bills, but if there is no public debt, then there will be no government securities to sell and buy them ( Stiglitz, 2015).

Consequently, J. Stiglitz believes that the traditional approach to the need to reduce the size of the budget deficit, the implementation of measures to reduce costs, radical savings does not improve, but worsens the financial condition of the state, as the aggregate demand decreases. At the same time, the enormous amount of the budget deficit and debt is a signal of the need for fiscal consolidation measures, but it is not clear what fiscal policy can be most effective.

In the book by J. Stiglitz ( Stiglitz, 2012), the author identifies three strategic directions of government action that can have a stimulating effect on the economy while maintaining public debt attention (Table 1).

Table 1

Strategies to stimulate the economy in the light of public debt

\begin{tabular}{|c|c|}
\hline Strategies & Content of strategies \\
\hline $\begin{array}{l}1 . \\
\text { Government } \\
\text { borrowing and } \\
\text { investment }\end{array}$ & $\begin{array}{l}\text { The state may borrow today to invest in } \\
\text { the future - for example, to provide quality } \\
\text { education for the poor and for the middle } \\
\text { class, to develop technologies that increase } \\
\text { the demand for skilled labor and at the } \\
\text { same time ensure the protection of the } \\
\text { environment. These high-yield investments } \\
\text { allow the government to pay off loans } \\
\text { at a very low rate. The return on public } \\
\text { investment is quite high, as it is possible } \\
\text { to attract credit resources cheaply and for } \\
\text { a long time. Today there is a demand for } \\
\text { government securities - treasury bills at } \\
\text { interest rates around zero. The strategy } \\
\text { of investing in the country's future in the } \\
\text { medium or long-term may reduce the } \\
\text { national debt, but in the short run the state } \\
\text { will borrow. }\end{array}$ \\
\hline $\begin{array}{l}2 . \\
\text { Balanced Budget } \\
\text { Multiplier. }\end{array}$ & $\begin{array}{l}\text { Taxes themselves slow down the growth rate } \\
\text { of the economy, but spending stimulates } \\
\text { them. A balanced increase in taxes and an } \\
\text { increase in budgetary expenditures leads to } \\
\text { GDP growth. If the current deficit remains } \\
\text { unchanged, it can be argued that these are } \\
\text { measures that stimulate the economy. The } \\
\text { magnitude of the growing GDP that comes } \\
\text { from increasing taxes and expenditures is a } \\
\text { multiplier of a balanced budget. At the same } \\
\text { time, GDP growth can be two to three times } \\
\text { higher than public spending. In the medium } \\
\text { term, while the budget deficit remains } \\
\text { unchanged - the debt of the state decreases } \\
\text { because of the increased tax revenues from } \\
\text { high GDP growth. }\end{array}$ \\
\hline $\begin{array}{l}3 . \\
\text { Stimulating the } \\
\text { economy within } \\
\text { the limits of } \\
\text { debt and deficit }\end{array}$ & $\begin{array}{l}\text { Stimulating the economy within the limits } \\
\text { of debt and deficit - which works, even if } \\
\text { the state can not increase their total size. } \\
\text { You can take advantage of the degree to } \\
\text { which different taxes and costs stimulate } \\
\text { the economy, spending more on programs } \\
\text { with large multipliers (where each spending } \\
\text { dollar produces more total GDP), and less for } \\
\text { programs with marginal margins. The strategy } \\
\text { is based on the feasibility of raising taxes on } \\
\text { the very rich citizens (including increased } \\
\text { taxation of passive income), lowering taxes on } \\
\text { low-income citizens. }\end{array}$ \\
\hline
\end{tabular}

Source: compiled by sources based on sources (Stiglitz 2012; Stiglitz 2015)

An effective public debt management strategy in Ukraine is a good combination of alternative debt and nondebt sources of financial and credit resources used by public authorities to fulfill their functions and is based on the benefits of each source and the elimination or mitigation of neg- 
ative impacts. At the same time, as can be seen from Figure 1 , non-tax sources of financing of the national economy include: taxes, non-tax revenues, income from operations with capital (including sale of land and intangible assets, transfers from international financial organizations and foreign governments (non-repayable financial assistance), reimbursement of budget funds from deposits, proceeds as a result of government securities sale, foreign direct investment, privatization, disclosure and disclosure by law enforcement of corrupt means of shadow sources, including illegally appropriated budget.

Debt sources include funds from government domestic and foreign borrowings. The implementation of financial policies for the rational use of domestic non-monetary and nondebt sources can significantly reduce the dependence of the country, in particular on external creditors.

Fig.1 Alternative sources of financing for the development of national economies

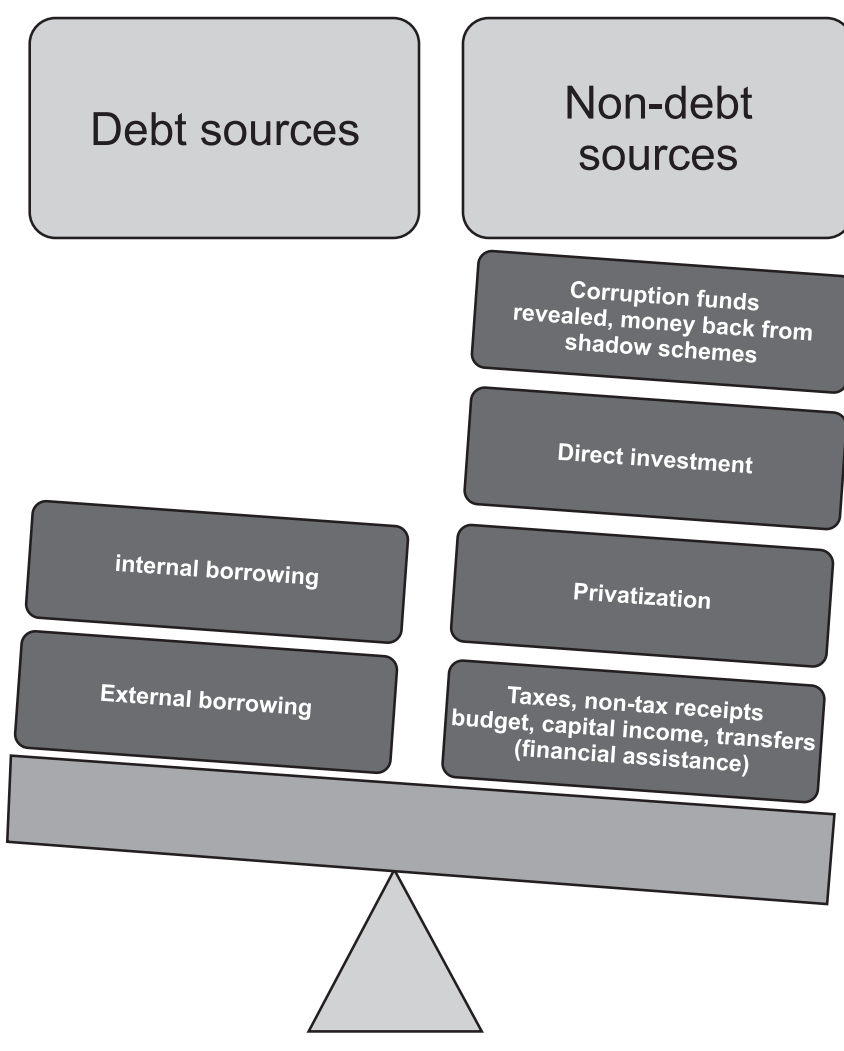

State debt directly or indirectly affects almost all areas of the functioning of the country's financial system, its economic security. Important components of public finance management are monitoring public debt and assessing the level of debt security, which involves analyzing the aggregate of indicators (Auerbach, 2015).

The list of indicators, their critical importance, as well as financial security measures are determined by each country on the basis of its own economic experience and under the influence of new internal or external threats in any sector of the economy and finance, based on the recommendations of the international financial institutions(Auerbach... 2018).
Underestimating the importance of choosing the criteria for assessing debt security in the management of public finances and determining their limit values leads to a decrease in the effectiveness of the management of financial resources of the state. In modern scientific financial science, the problem of choosing methods for constructing a system of weighted indicators, their adaptation to the requirements of the current level of economic development is sufficiently thoroughly considered in the works of T. Bogdan, V. Kozyuk, V. Lisovenko and others.

Proceedings by T. Bogdan are characterized by a systematic vision in assessing the risks of debt financing of the budget deficit, threats to external lending. It determines the most informative and significant indicators of debt security: state and state -guaranteed debt in\% of GDP; state and stateguaranteed debt in \% of the state budget revenues; gross external debt in\% to exports of goods and services; repayment and servicing of public debt in \% of budget revenues; repayment and servicing of long-term external cumulative debt in $\%$ to exports of goods and services; short-term external cumulative debt at maturity in \% of the international reserves of the country ( Bogdan, 2019).

During the last decade, conceptual approaches to the methodology for calculating the level of debt security of the country as a component of financial security in government regulations have changed several times. Table 2 provides a comparative table on changes in the list of debt security indicators in the normative documents of the Ministry of Economic Development and Trade of Ukraine (2019).

Table 2

Indicators of the level of debt security are defined in the orders of the Ministry of Economic Development and Trade of Ukraine

\begin{tabular}{|l|l|}
\hline $\begin{array}{l}\text { Indicators of the level of debt } \\
\text { security in accordance with } \\
\text { the Order «On approval of the } \\
\text { methodology for calculating } \\
\text { the level of economic } \\
\text { security of Ukraine», dated } \\
02.03 .2007 \text { No.60 }\end{array}$ & $\begin{array}{l}\text { Indicators of the level of debt } \\
\text { security in accordance with } \\
\text { the Order of the Ministry of } \\
\text { Economic Development and } \\
\text { Trade of Ukraine «Methodical } \\
\text { recommendations for } \\
\text { calculating the level of economic } \\
\text { security of Ukraine», dated } \\
\text { 29October 2013 No. 1277 }\end{array}$ \\
\hline expired & current \\
\hline $\begin{array}{l}\text { 1.The ratio of the total public } \\
\text { debt to GDP, no more than }\end{array}$ & $\begin{array}{l}\text { 1.The ratio of the state and } \\
\text { guaranteed by the state debt to } \\
\text { GDP, percents }\end{array}$ \\
\hline $\begin{array}{l}\text { 2.The ratio of the total } \\
\text { external debt to GDP, no more } \\
\text { than 25\% }\end{array}$ & $\begin{array}{l}\text { 2.The ratio of gross external } \\
\text { debt to GDP, percents }\end{array}$ \\
\hline $\begin{array}{l}\text { 3.The level of external debt } \\
\text { per person, no more than } 200 \\
\text { dollars USA }\end{array}$ & $\begin{array}{l}\text { 3.Average weighted yield of } \\
\text { domestic government loan } \\
\text { bonds in the primary market, } \\
\text { percents }\end{array}$ \\
\hline $\begin{array}{l}\text { 4.The ratio of the state } \\
\text { external debt to the annual } \\
\text { exports of goods and services, } \\
\text { no more than 70\% }\end{array}$ & 4.EMBI index \\
\hline
\end{tabular}




\begin{tabular}{|l|l|}
\hline $\begin{array}{l}\text { 5.Interest rate relation with } \\
\text { servicing external debt to } \\
\text { annual exports of goods and } \\
\text { services, no more than } 12 \%\end{array}$ & $\begin{array}{l}\text { 5.The ratio of official } \\
\text { international reserves to the } \\
\text { volume of gross external debt, } \\
\text { percents }\end{array}$ \\
\hline $\begin{array}{l}\text { 6.The ratio of total payments } \\
\text { for external debt servicing to } \\
\text { the state budget revenue, no } \\
\text { more than } 20 \%\end{array}$ & \\
\hline $\begin{array}{l}\text { 7.The ratio of domestic debt } \\
\text { to GDP, no more than } 30 \%\end{array}$ & \\
\hline $\begin{array}{l}\text { 8.The ratio of aggregate } \\
\text { payments for servicing } \\
\text { domestic debt to the state } \\
\text { budget revenues, no more } \\
\text { than } 25 \%\end{array}$ & \\
\hline $\begin{array}{l}\text { 9.The ratio of government } \\
\text { debt to government gross } \\
\text { domestic product, no more } \\
\text { than } 30 \%\end{array}$ & \\
\hline
\end{tabular}

Source: compiled by authors on the basis of the Ministry of Economic Development and Trade of Ukraine (2019)

In accordance with the Order of the Ministry of Economic Development and Trade No. 1277 (expired), "debt security the appropriate level of internal and external debt, taking into account the cost of its servicing and the efficiency of using domestic and foreign borrowings and the optimum balance between them, sufficient to meet the urgent socio-economic needs that does not threaten the sovereignty of the state and its financial system", the list of indicators is an integral part of economic security - debt security includes five indicators listed without indicating critical limitation: the ratio of state and public state-guaranteed debt to GDP, percent (the amount of state and state-guaranteed debt, million UAH / GDP, million $\mathrm{UAH} \times 100$ ); the ratio of gross external debt to GDP, percent (gross external debt, million USD $\times$ average exchange rate of UAH to USD / GDP, million UAH x 100); the average weighted yield of domestic government bonds (hereinafter - OVDPs) in the primary market, percentages; EMBI (Emerging Markets Bond Index) + Ukraine; the ratio of the volume of official international reserves to the volume of gross external debt, percent (the volume of official reserve assets, million USD/ volume of gross external debt, million USD x 100).

However, in defining debt security, emphasis is placed on the level of domestic and foreign government debt, the cost of its servicing, the efficiency of the use of internal and external borrowings, which are not fully or completely reflected in the approved safety indicators, which needs further refinement.

While paying tribute to the scientific work of domestic and foreign scientists on this issue, it should be emphasized that there is a need for further study of modern methods of debt analysis in Ukraine. In our opinion, the content component of the main indicators of debt security should be the following:

1) the proportion of state and guaranteed debt to GDP is one of the most important indicators of the state of public finances, allows you to determine the impact of debt obli- gations on the macroeconomic balance of the country as a whole, provides international comparability of data. However, this indicator does not, in essence, reflect the quality of the debts of the borrowing countries, since among the high-debt countries there are sufficiently strong developed countries with stable economies and attractive conditions for foreign investors;

2) rates on debt instruments (value of loans) - the cost of borrowing as a weighty indicator in the system of public debt management;

3) an increase in budget deficits and public debt - reflects the size of the need to finance a budget deficit at the expense of internal and external financing, forming a public debt;

4) the share of state budget expenditures for servicing government and government-guaranteed debt - reflects the credit burden on the budget, its value for all taxpayers and characterizes the size of the state's lost opportunities in financing education, modern technology, defense, social protection and social security, infrastructure objects and other areas in the annual budget;

5) the share of external and internal debt in the total amount of the public debt, the value of this indicator, as a rule, indicates the defined priorities of the state debt policy regarding the sources of financing the budget deficit, taking into account the conditions and the price (interest rates) on credit resources both on the domestic and on international financial markets. In addition, it determines the dependence on external creditors, for example, of borrowing countries' obligations to fulfill certain conditions for obtaining loans, in particular, another tranche from international financial institutions;

6) the share of short-term, medium-term and long-term loans in the state borrowing portfolio;

7) the ratio of external debt to exports;

8) the ratio of external debt to gold and foreign exchange reserves.

Good governance of public debt can be a factor in investment and innovation growth, improving welfare. Monitoring can cover the characteristics of a wide range of credit relations between actors.

In accordance with Article 18 of the Budget Code, the total amount of state and state-guaranteed debt at the end of the budget period can not exceed $60 \%$ of the annual nominal volume of Ukraine's GDP. In case of expected exceedance of this limit, the Cabinet of Ministers of Ukraine immediately addresses to the Verkhovna Rada of Ukraine the permission to temporarily exceed this limit and submits for approval the plan of measures for bringing the total amount of public debt and guaranteed state debt to the established requirements.

However, in the period from 2011 to 2016, the state and guaranteed debt in relation to GDP increased rapidly from $35.9 \%$ to $81.0 \%$, with peak growth for $2013-2014$ (from $40.1 \%$ to $70.2 \%$, respectively, as shown in Table 3, Fig.2).

In the table for state and state-guaranteed debt, the data is shown as of 31.12 (i.e. in column 2013, data are recorded as of December 31, 2013), and for GDP is indicated for the whole year. 
Table 3. State and state-guaranteed debt to GDP

\begin{tabular}{|c|c|c|c|c|c|c|c|c|c|c|}
\hline \multirow{2}{*}{$\begin{array}{c}\text { State and state } \\
\text { guaranteed } \\
\text { debt (total) }\end{array}$} & 2009 & 2010 & 2011 & 2012 & 2013 & 2014 & 2015 & 2016 & 2017 & 2018 \\
\cline { 2 - 11 } & 316885 & 432235 & 473122 & 515511 & 584114 & 1100564 & 1572180 & 1929759 & 2141674 & 2168627 \\
\hline \multirow{2}{*}{$\begin{array}{c}\text { Gross Domestic } \\
\text { Product (GDP) }\end{array}$} & 913345 & 1082569 & 1316600 & 1408889 & 1454931 & 1566728 & 1979458 & 2383182 & 2982920 & $\begin{array}{c}3558 \\
706\end{array}$ \\
\cline { 2 - 44 } & $+36.4 \%$ & $+9.5 \%$ & $+9.0 \%$ & $+13.3 \%$ & $+88.4 \%$ & $+42.9 \%$ & $+22.7 \%$ & $+11.0 \%$ & $1.3 \%$ \\
\hline $\begin{array}{c}\text { Government } \\
\text { debt/GDP }\end{array}$ & $34,7 \%$ & $39,9 \%$ & $35,9 \%$ & $36,6 \%$ & $40,1 \%$ & $70,2 \%$ & $79,4 \%$ & $81,0 \%$ & $71,8 \%$ & $61 \%$ \\
\hline
\end{tabular}

Fig.2. State and state-guaranteed debt of Ukraine and GDP in 2012-2018, UAH

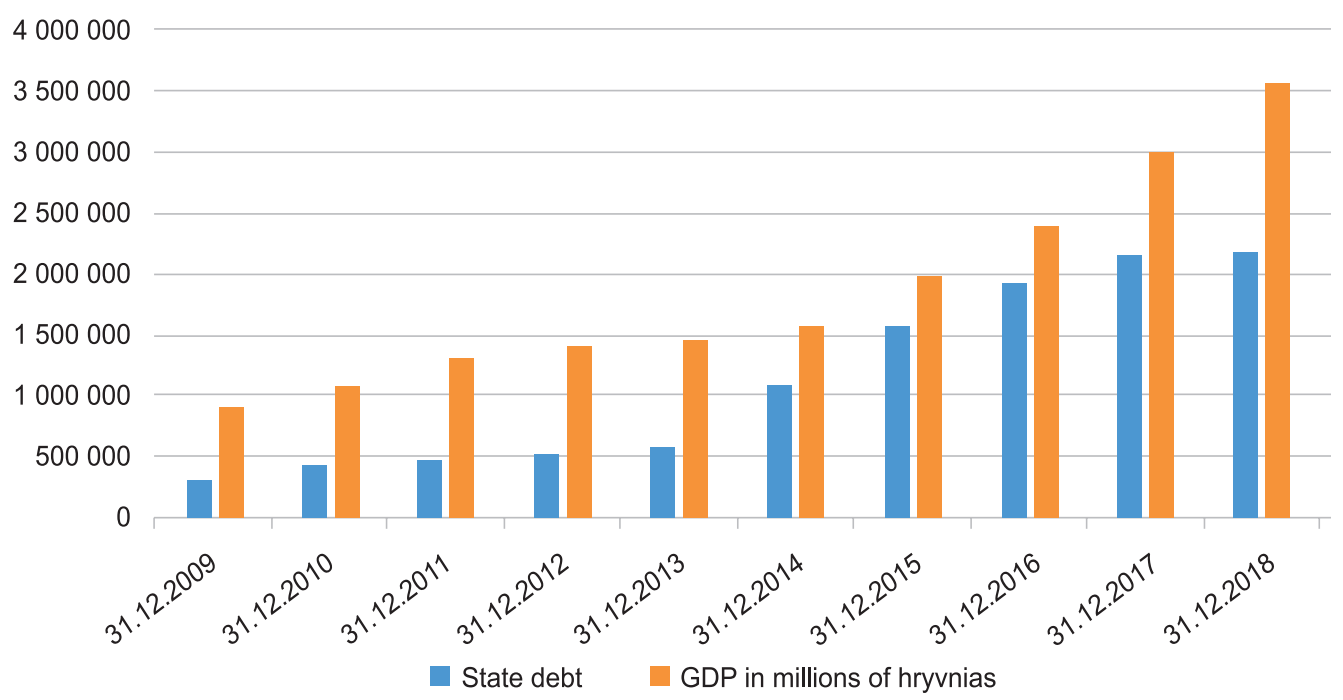

ance with the Resolution of the Cabinet of Ministers of Ukraine of 28.12.2016 No. 1003, the devaluation of the national currency, the rate of which against the US dollar increased from about $24.00 \mathrm{UAH} / \mathrm{USD}$ at the end of 2015 to about $27.19 \mathrm{UAH}$ / USD at the end of December 2016.

The total amount of state and state-guaranteed debt as at 31.12.2017 amounted to $85.62 \%$ of the state debt and $14.38 \%$ of the guaranteed debt. As of December 31, 2018, (UAH 2168,45 billion) the total

Source: Own calculations based on Ukrainian Ministry of Finance (MoF) data

The reasons for the sharp rise in debt are excessive growth of government expenditures over the growth rates of government revenues, raising funds in order to maintain the stability of the national currency and ensure national defense. Also, the reason for growth is the financing of the state budget at the expense of state borrowings, the capitalization of PJSC KB "PRIVATBANK" in accordance with the Resolution of the Cabinet of Ministers of 18.12.2016. No. 961 (as amended) and the Guarantee Fund for Individuals Deposits in accord- amount of the state and state-guaranteed debt amounted to $85.79 \%$ of the state debt and $14.21 \%$ of the guaranteed debt. Over the past 5 years, the significant growth of Ukraine's public debt has taken place in 2013 with UAH 480.22 billion. to UAH 1833.70 billion in 2017. As of December 31, 2018, the state debt of Ukraine is UAH 1860,29 billion, which is no less than the state debt for 2017. And the state debt had a weak tendency to decrease (Fig.3)

Fig.3. State and state-guaranteed debt of Ukraine in 2012-2018

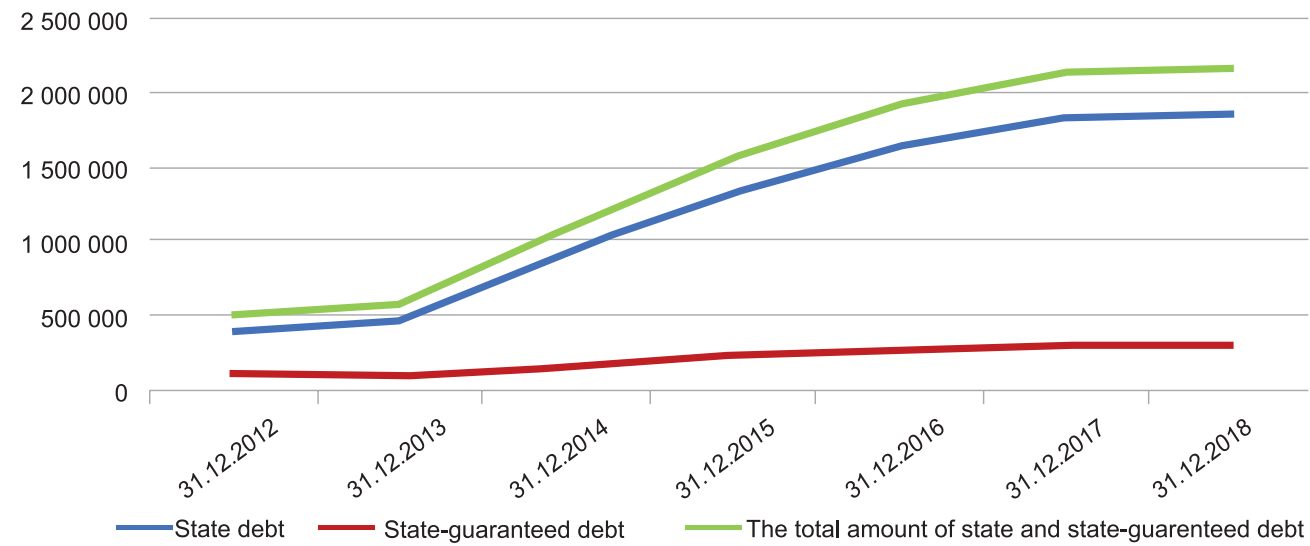

Source: Ukrainian Ministry of Finance (MoF) data
The vast majority (64.2\%) in 2017 were external debt obligations. As of June 30,2018 , the ratio decreased and amounted to $61.8 \%$. As of December 31, 2018 - 64.4\% (UAH 1397,01 billion).

The specific weight of expenditures of the State Budget of Ukraine for debt servicing for the period of 2012-2018 changed in the following way (Table 4). 
Table 4. Specific weight of expenditures of the State Budget of Ukraine for debt service for the period of 2012-2018

\begin{tabular}{|c|c|c|c|c|c|c|c|}
\hline & 2012 & 2013 & 2014 & 2015 & 2016 & 2017 & 2018 \\
\hline $\begin{array}{c}\text { Expenditures on servicing } \\
\text { the national debt, million } \\
\text { UAH }\end{array}$ & 24197 & 31677 & 47977 & 84505 & 95794 & 110456 & 115431 \\
\hline \begin{tabular}{c} 
Cost share \\
\hline
\end{tabular} & $6,1 \%$ & $7,9 \%$ & $11,2 \%$ & $14,7 \%$ & $14,0 \%$ & $13,2 \%$ & $11,7 \%$ \\
\hline
\end{tabular}

Fig.4. Share of expenditures of the State Budget of Ukraine for debt service

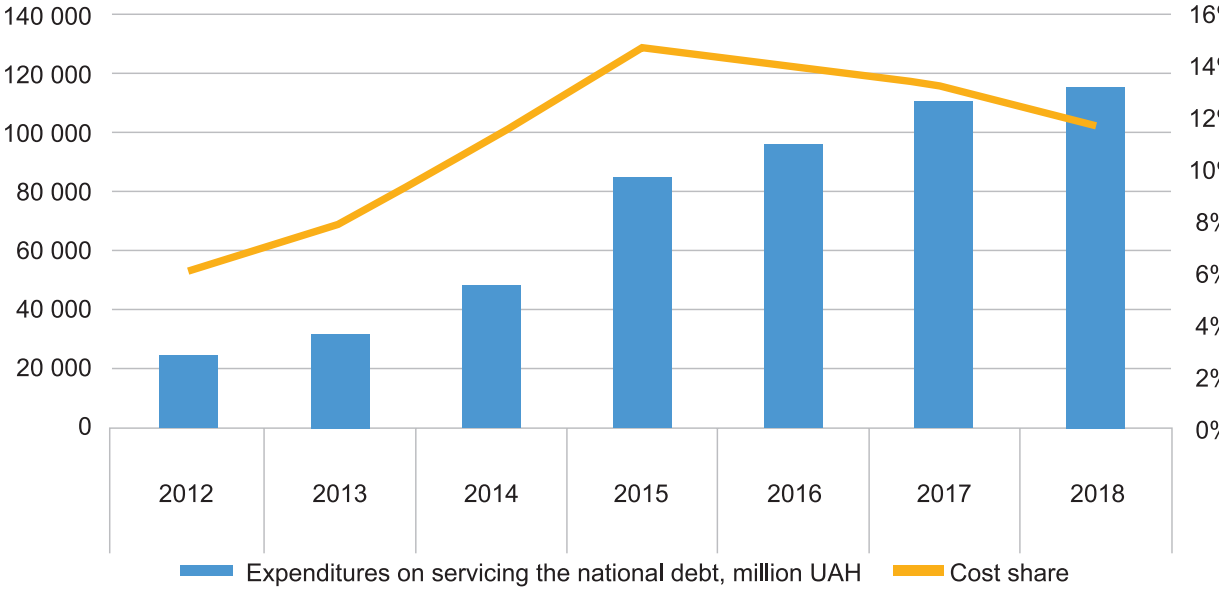

Source: Ukrainian Ministry of Finance (MoF) data

Thus, the volume of expenditures of the State Budget of Ukraine for servicing the debt for the period of 2012-2017 grew almost in proportion to the volume of borrowings. The decrease in the share of the expenditures of the State Budget of Ukraine for debt servicing in 2017 by $1.5 \%$ compared to 2015 decreased due to an increase in the total volume of expenditures of the consolidated State Budget of Ukraine and does not indicate a positive dynamics in the context of our study.

As for the indicator, the share of payments for servicing debt in the state budget expenditures: in 2015, this share amounted to $15 \%$ of budget expenditures. In recent years, this percentage has fallen to $13.2 \%$ in 2017 and to $11.7 \%$ in 2018 .

There is a difference between gross external debt and external debt. The gross external debt as of a certain date is the total amount of arrears for all existing, but in no case contingent liabilities to be paid by the debtor in the form of principal and / or $10 \%$ interest at any time in the future, $8 \%$ which are liabilities of residents of this economy to non-residents.

External debt - is the total $4 \%$ amount of debt obligations of the $2 \%$ state of the external market for $0 \%$ the return of received and outstanding loans (loans) as of the reporting date due to the state borrowing.

The indicator of gross external debt allows you to analyze both the state of the public finance sector and the corporate. It includes direct government debt, loans received from the NBU by the IMF and international financial institutions, liabilities of local governments for debt securities and external loans, liabilities of banks for debt securities, loans and deposits, liabilities of the real economy sector of Ukraine on debt securities, borrowed loans (including guarantees guaranteed by the government) and accounts payable (trade long-term and short-term loans and overdue fences for them).

Consequently, gross external debt is a more aggregate indicator compared to external debt.

In the table for external debt, data is specified as of 31.12 (ie in column 2013, data are recorded as of December 31, 2013), and data for GDP is specified for the whole year (Table 5).

Table 5. Gross external debt per capita

\begin{tabular}{|c|c|c|c|c|c|}
\hline Year & \multicolumn{2}{|c|}{ External debt (per capita) } & \multicolumn{2}{c|}{ GDP of Ukraine (per capita) } & Population (thousand)* \\
\hline 2006 & 1161,6 & & 2296,1 & & 46930 \\
\hline 2007 & 1714,1 & $+47.6 \%$ & 3059,6 & $+33.3 \%$ & 46646 \\
\hline 2008 & 2192,2 & $+27.9 \%$ & 3881,4 & $+26.9 \%$ & 46373 \\
\hline 2009 & 2240,7 & $+2.2 \%$ & 2540,5 & $-34.5 \%$ & 46144 \\
\hline 2010 & 2553,0 & $+13.9 \%$ & 2968,0 & $+16.8 \%$ & 45963 \\
\hline 2011 & 2762,4 & $+8.2 \%$ & 3570,4 & $+20.3 \%$ & 45698 \\
\hline 2012 & 2963,3 & $+7.3 \%$ & 3856,7 & $+8.0 \%$ & 45579 \\
\hline 2013 & 3123,5 & $+5.4 \%$ & 4029,9 & $+4.5 \%$ & 45487 \\
\hline 2014 & 2884,5 & $-7.6 \%$ & 3010,1 & $-25.3 \%$ & 43788 \\
\hline 2015 & 2771,3 & $-3.9 \%$ & 2115,1 & $-29.7 \%$ & 42842 \\
\hline 2016 & 2660,0 & $-4.0 \%$ & 2185,6 & $+3.3 \%$ & 42675 \\
\hline 2017 & 2744,0 & $+3.2 \%$ & 2639,9 & $+20.8 \%$ & 42485 \\
\hline 2018 & 2713,2 & $-1.1 \%$ & 3094,5 & $+17.2 \%$ & 42279 \\
\hline 31.06 .2019 & 2747,1 & $1.3 \%$ & & & 42048 \\
\hline
\end{tabular}

* the average value for the year from 2014 - without taking into account the occupied territories (Crimea, Sevastopol, parts of Donbass)

Source: Ukrainian Ministry of Finance (MoF) data 
Starting from 2015, the external debt per capita has grown to more than the GDP of Ukraine per capita. Also, from 2014, the data in Table 5 are given without occupied territories (Crimea, parts of the Donbas).

The ratio of the external debt of Ukraine and its gold and foreign exchange reserves does not demonstrate the stability shown in Table 6 . The debt begins to chronologically outperform Ukraine's currency reserves and as of December 31, 2017, it covered only $38.4 \%$. As at 31.12.2017, the external debt amounted to USD 48989 million.

Thus, while gold and foreign exchange reserves amounted to USD 18808 million, however as of June 30, 2018, the external government debt amounted to USD 47159 million, which is 3.7\% less than in 2017. As of December 31, 2018, the external government debt amounted to USD 50460 million. And the debt had a weak tendency to increase.

Table 6. Ratio of external state debt of Ukraine and its gold and foreign currency reserves

\begin{tabular}{|c|c|c|c|}
\hline \multicolumn{4}{|c|}{ Dynamics of external state debt and international reserves of Ukraine from 2010 to 2019 (in millions of US dollars) } \\
\hline Year & External State Debt & Gold and currency reserves & $\begin{array}{c}\text { Gold and currency reserves / } \\
\text { national debt }\end{array}$ \\
\hline 31.12 .2009 & 26518,7 & 26505,0 & $99.9 \%$ \\
\hline 31.12 .2010 & 34759,6 & 34576,0 & $99.5 \%$ \\
\hline 31.12 .2011 & 37474,5 & 31794,6 & $84.8 \%$ \\
\hline 31.12 .2012 & 38658,8 & 24546,2 & $63.5 \%$ \\
\hline 31.12 .2013 & 37536,0 & 20415,7 & $54.4 \%$ \\
\hline 31.12 .2014 & 38792,2 & 7533,3 & $19.4 \%$ \\
\hline 31.12 .2015 & 43445,4 & 13300,0 & $30.6 \%$ \\
\hline 31.12 .2016 & 45604,6 & 15539,3 & $34.1 \%$ \\
\hline 31.12 .2017 & 48989,2 & 18808,0 & $38.4 \%$ \\
\hline 31.12 .2018 & 50462,0 & 20820,4 & $41.3 \%$ \\
\hline
\end{tabular}

Source: Ukrainian Ministry of Finance (MoF) data

According to forecasts, in 2016, the level of external debt in the annual calculation will be 3.5 times higher than export revenues, which is $40 \%$ worse than last year's figure.

Thus, this year, the country's ability to service its foreign liabilities at the expense of foreign exchange earnings from foreign economic activity is significantly reduced.

Fig.6. External state debt gold and currency reserves

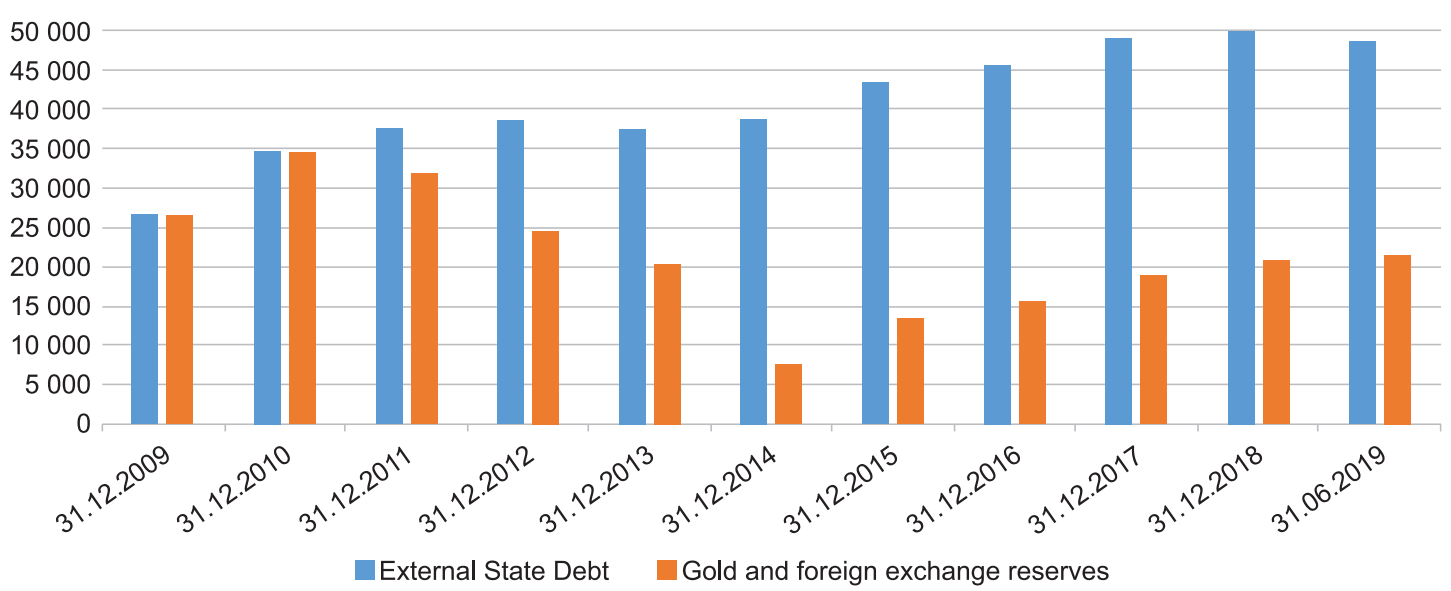

Source: Ukrainian Ministry of Finance (MoF) data 
Next (Table7), the graph shows the ratio between gross external debt and international reserves.

Table 7. The ratio of gross external debt to international reserves

\begin{tabular}{|c|c|c|c|c|c|c|c|c|}
\hline Year & 31.12 .11 & 31.12 .12 & 31.12 .13 & 31.12 .14 & 31.12 .15 & 31.12 .16 & 31.12 .17 & 31.12 .18 \\
\hline International reserves, mln. & 31794 & 24546 & 20415 & 7533 & $13299 w$ & 15539 & 18808 & 20820,43 \\
\hline Gross External Debt, mln. & 126236 & 134625 & 142079 & 126308 & 118729 & 113518 & 116578 & 114710 \\
\hline Debt / Reserve & 3,97 & 5,48 & 6,96 & 16,77 & 8,93 & 7,31 & 6,2 & 5,51 \\
\hline
\end{tabular}

The sources are the Ministry of Finance: [24].

As we see in the table, from 2011 to 2014 the situation was rapidly deteriorating, gross external debt was higher than international reserves at 16.77 times in 2014, but in 2015, due to the NBU and Cabinet of Ministers activities, the situation improved and debt is 9 times higher than international reserves of Ukraine. And in the future, we also see an improvement in the situation; by 2018 , the debt is only 5,5 times higher than the international reserves of Ukraine.

\section{CONCLUSIONS}

The formation of a state debt management strategy requires a significant revision of priority goals and objectives and the improvement of instruments for their implementation. State debt in Ukraine remains a significant factor of macro-financial risk. An important measure to prevent the threat of uncontrolled growth of public debt is to strengthen financial control and the implementation of continuous monitoring of its main indicators. The cost of public borrowing and the assessment of the effectiveness of their use as a factor in ensuring the sustainable development of the economy is a constant source of discussion between officials, public organizations, and representatives of scientific analysis centers.

In modern conditions, at least two key indicators of debt security are certain at the legislative level in Ukraine. In particular, in accordance with Article 18 of the Budget Code of Ukraine, the following indicators are fixed:

- The limit value of public debt and state-guaranteed debt at the end of the budget period (calendar year) to gross domestic product cannot exceed $60 \%$ of Ukraine's annual nominal GDP, taking into account the provisions of Article 14 of the Budget Code of Ukraine, where the maximum amount of the state budget deficit is set for each year of the medium term at the level of $3 \%$ of the forecast of nominal volume of Ukraine's GDP for the corresponding year;

- annually, the absolute value of state and state-guaranteed debt (debt ceiling of borrowings) for the budget year in UAH equivalent is determined by the Law of Ukraine on the State Budget.

The empirical experience of developed EU countries confirms the feasibility of using the key benchmark of state debt to GDP of $60 \%$ in government debt management. At the same time, the maximum level of public debt for emerging markets is proposed in the range of $40-60 \%$. These ideas were embodied in the position of the medium-term state debt management strategy for 2018-2020 years, where the planned gradual reduction of public debt to GDP is $60 \%$ as of 2018, up to $52.2 \%$ in 2019 and up to $49 \%$ in 2020 .
Consequently, it is important to monitor compliance with the established expected values during the budget periods defined by the strategic plans for monitoring and justifying the actually obtained indicators. In this context, the actual indicator of Ukraine's debt in 2018 was $68 \%$, which indicates a deviation from the planned indicator, which was due to the presence of internal and external factors which were not taken into account when this indicator was planning and which need to be further studied. So, the quality of debt planning needs further improvement.

In addition, the group of indicators of debt security should include the indicator of external government debt short-term external debt as a percentage of reserves (threshold value - 100\%), from 2014 this indicator is constantly exceeded.

In the past five years, a negative factor in Ukraine is a steady tendency to refinance state debt at the expense of a state loan, in which borrowings are not spent on financing projects for socio-economic development, but are used to repay previously received loans. At the same time, in recent years, the possibilities of borrowing funds within the framework of development projects implemented with the support of the IFIs and $\mathrm{KfW}$ are being used in a timely manner and not in full (only by $50 \%$ ).

The next indicator that needs to be considered is the cost of servicing the state debt. Unreasonable, in our opinion, is the phenomenon when loans with a lower rate are repaid early. Given the low credit ratings of Ukraine, the cost of attracting credit resources remains very expensive, thus, the current rate for short-term bonds is $19.5 \%$, for five-year bonds it is $16 \%$. This situation is beneficial for investors who invest their money for a short period at high rates, get high profits and, if any crisis occurs, tend to quickly leave the government securities market without loss.

That is, when investors are non-residents, as the domestic practice of the Ukrainian government bonds market has repeatedly shown, the threat of a mass outflow from the bondholders' market increases, usually accompanied by an increase in demand for foreign currency, a devaluation of the national currency and a reduction in the NBU reserves. The balance of debt security today is upset by excessive payments on the servicing of public debt - this figure has fluctuated from 10 to $15 \%$ of all state budget expenditures over the past five years (the latter value is a critical level of servicing government borrowing from the budget).

In addition, in the short term, a factor associated with the conditions of the restructuring of state debt of Ukraine in 2015, according to which the annual amounts of debt pay- 
ments will depend on the magnitude of GDP growth in the country, may join the factors of debt danger. In particular, in servicing the public external debt in 2019 the largest share was taken by payments on the issued in the result of the restructuring of government bonds in 2015 in the amount of UAH 26128.2 million.

We note a tendency to a significant excess of external borrowing over domestic, respectively, in the structure of borrowing currency, foreign currency prevails over domestic, characterized by the country's dependence on external creditors, in particular, the increasing influence of international financial organizations on budget debt, monetary, pension, land, tariff, export import and other areas of government economic policy.

A timely measure should be the creation of a professional and independent institution - a government debt management agency in Ukraine, whose specialists would be experts and active participants in the financial market and who are able to quickly respond to fluctuations in interest rates, the cost of securities and to orient in capital movement trends in international financial markets. The agency should become an alternative to state institutions that traditionally specialized in the implementation of tactical measures in the field of debt policy in the stock market.

\section{REFERENCES:}

1. Auerbach, A. (2015). Fiscal Uncertainty and How to Deal With It. Proceedings. Annual Conference on Taxation and Minutes of the Annual Meeting of the National Tax Association, 108, 1-29. URL:www.jstor.org/stable/90023221

2. Auerbach, A., Gale W., Krupkin A. (2018). The Federal Budget Outlook: We Are Not Winning. URL: https://www.brookings.edu/wp-content/uploads/2018/09/ES_20180904_Gale-Budget-Outlook.pdf

3. Bogdan, T. P. (2019). Analysis of the state debt management of Ukraine in I quarter of 2019 URL: http:// optimacenter.org/userfiles/\%D0\%90\%D0\%BD\%D0\%B0\%D0\%BB\%D1\%96\%D0\%B7\%20\%D1\%83\%D0\%BF\%D1\%80\%D0\%B0\%D0\%B2\%D0\%BB\%D1\%96\%D0\%BD\%D0\%BD\%D1\%8F\%20\%D0\%B4\%D0\%B5\%D1\%80\%D0\%B6\%D 0\%B0\%D0\%B2\%D0\%BD\%D0\%B8\%D0\%BC\%20\%D0\%B1\%D0\%BE\%D1\%80\%D0\%B3\%D0\%BE\%D0\%BC\%20\%D1\%83\%20 \%D0\%86\%20\%D0\%BA\%D0\%B2\%D0\%B0\%D1\%80\%D1\%82\%D0\%B0\%D0\%BB\%D1\%96\%202019\%20\%D1\%80\%D0\%BE\%D0\%BA\%D1\%83.pdf

4. Bogdan, T. P. (2013). Debt policy of the state in the conditions of global instability. Economy of Ukraine, (2), 4-17.

5. Bogdan, T. P. (2014). Trends in the global financial market under the influence of debt processes in developed countries. Finance of Ukraine, (7), 31-48.

6. Chugunov, I. Ya., \& MAKOGON, V. (2014). Budget and tax policy in the context of institutional reforms. KNETE Bulletin, (4), 79-91.

7. Lisovenko, V., Bench, L. Ya., \& Betz, O. I. (2014). Public Debt: Conceptual Principles and Macroeconomic Aspects. Finances of Ukraine, (12), 7-31.

8. Liutyy, I., Zrazhevska, N., \& Rozhko, O. (2008). State credit and debt policy of Ukraine: monograph: TSUL.

9. Ministry for Development of Economy, Trade and Agriculture of Ukraine. URL: http://www.me.gov.ua/?lang=en-GB

10. Ministry of Finance of Ukraine URL: https://mof.gov.ua/en/news/derzhavnii_borg_zmenshuietsia-1872

11. Paentko, T.. (2013). The institutional nature of the budget deficit and public debt in Ukraine. Economy of industry.

12. Rozhko, O. Muzychenko V. .(2013). Borgova Ukraine's Security in the Context of the Global Financial Crisis. Effective Economics. Electronic scientific professional edition.№ 3: URL: http://www.economy.nayka.com.ua.

13. Sidelnikova, L.P. (2013). Apologetics of the tax and debt component of the fiscal policy of Ukraine.

14. Sidelnikova, L.P. (2014). Development of budget resources in the context of the evolution of state-building. Finance of Ukraine, (8), 70.

15. Sidenko, V. Yurchishin, V. Markevich K. (2015). Debts: time to take and give time. Global Trends and Challenges for Ukraine, URL: http://old.razumkov.org.ua/upload/1444658448_file.pdf

16. Stiglitz, J. (2015). The great divide. Penguin UK.

17. Stiglitz, J. E. (2012). The price of inequality: How today's divided society endangers our future. WW Norton \& Company.

18. The Budget Code of Ukraine: Law of Ukraine on July 8, 2010, No. 2456-VI. URL: http: // zakon3.rada.gov.ua/laws/ show/2755-17/ed20150101 (Accessed 4 May 2019).

19. Vakhnenko, T., Zrazhevska, N., Kozyuk, V., Lyutyy, I., Malerik, M., Rozhko, O., ... \& Sharov, O. (2011). Problems of formation and servicing of external state debt of Ukraine. 


\section{MONITORING OF KEY INDICATORS OF THE STATE DEBT OF UKRAINE: MODERN TRENDS}

\section{LYUTYY IGOR}

Doctor of Economics, Professor

Chief of Finance Department

Taras Shevchenko National University of Kyiv, Ukraine yljuda@ukr.net

\section{NAKONECHNA YULIIA}

PhD in Economics, Associate Professor,

Taras Shevchenko National University of Kyiv, Ukraine

tematika@ukr.net

\author{
DEMYDENKO LIUDMYLA \\ $\mathrm{PhD}$ in Economics, Associate Professor, \\ Taras Shevchenko National University of Kyiv, Ukraine \\ ipr.demydenko@gmail.com
}

\section{KEYWORDS: PUBLIC DEBT OF UKRAINE, GUARANTEED BY THE STATE DEBT, INTERNAL LENDERS, EXTERNAL} LENDERS, DEBT SERVICING, DEBT SECURITY, GOVERNMENT DEBT POLICY, PUBLIC FINANCES.

For citation: Lyutyy I., Nakonechna Y., Demydenko L. (2019), Monitoring of Key Indicators of the State Debt of Ukraine: Modern Trends, Globalization And Business, №8, pp. 34-43. https://doi.org/10.35945/gb.2019.08.003

\section{SUMMARY}

The article contains a theoretical generalization of the essence and necessity of state borrowing, monitoring of indicators of state and state-guaranteed debt in the conditions of government aspirations and actions in the field of ensuring the sustainability of public finances in Ukraine. The main task of the authors is to monitor the indicators of state and state-guaranteed debt in the context of the need to ensure the sustainability of public finances of Ukraine. State debt in Ukraine remains a significant factor of macro-financial risk. An important measure to prevent the threat of uncontrolled growth of public debt is to strengthen financial control and the implementation of continuous monitoring of its main indicators. The cost of public borrowing and the assessment of the effectiveness of their use as a factor in ensuring the sustainable development of the economy is a constant source of discussion between officials, public organizations, and representatives of scientific analysis centers.

The article uses the generally accepted methodology for calculating the main indicators characterizing the state's debt policy. The method of expert assessments analyzes the condition of the state debt and prospects of its servicing in Ukraine. Statistical and analytical methods have been used for the processing of statistical data on the study of the dynamics of indicators of state and state-guaranteed debt in Ukraine. The sources of information were the materials of the Ministry of Finance of Ukraine, the State Treasury Service of Ukraine, as well as the Budget Code of Ukraine, laws and regulations of Ukraine relating to the budget sphere, scientific works of domestic and foreign scientists. This study aims to address the issues of analyzing and evaluating public debt indicators in the context of improving debt management. The authors propose to use 10 indicators to monitor the state of public debt and make managerial decisions in public finance.

The empirical experience of developed EU countries confirms the feasibility of using the key benchmark of state debt to GDP of $60 \%$ in government debt management. At the same time, the maximum level of public debt for emerging markets is proposed in the range of $40-60 \%$. These ideas were embodied in the position of the medium-term state debt management strategy for 2018-2020 years, where the planned gradual reduction of public debt to GDP is $60 \%$ as of 2018 , up to $52.2 \%$ in 2019 and up to $49 \%$ in 2020 .

Consequently, it is important to monitor compliance with the established expected values during the budget periods defined by the strategic plans for monitoring and justifying the actually obtained indicators. In this context, the actual indicator of Ukraine's debt in 2018 was $68 \%$, which indicates a deviation from the planned indicator, which was due to the presence of internal and external factors which were not taken into account when this indicator was planning and which need to be further studied. So, the quality of debt planning needs further improvement. In addition, the group of indicators of debt security should include the indicator of external government debt - short-term external debt as a percentage of reserves (threshold value - 100\%), from 2014 this indicator is constantly exceeded.

The dynamics of changes in the state debt and state-guaranteed debt to the main macroeconomic indicators and budget parameters, weaknesses of the government debt strategy, the prospects of the debt policy in Ukraine are determined. 